Article

\title{
An Environmental Risk Assessment of Filling Stations Using the Principles of Security Management. A Case Study in the Slovak Republic
}

\author{
Katarína Mäkká ${ }^{1, *}$, Katarína Kampová ${ }^{1}$, Tomáš Loveček ${ }^{1}$ and Katarína Petrlová ${ }^{2}$ \\ 1 Faculty of Security Engineering, University of Žilina, Univerzitná 8215/1, 01026 Žilina, Slovakia; \\ katarina.kampova@uniza.sk (K.K.); tomas.lovecek@uniza.sk (T.L.) \\ 2 Mathematical Institute in Opava, Silesian University in Opava, Na Rybníčku 626/1, \\ 74601 Opava, Czech Republic; Katarina.Petrlova@math.slu.cz \\ * Correspondence: Katarina.Makka@uniza.sk; Tel.: +421-41-513-6666
}

\section{check for} updates

Citation: Mäkká, K.; Kampová, K.; Loveček, T.; Petrlová, K. An Environmental Risk Assessment of Filling Stations Using the Principles of Security Management. A Case Study in the Slovak Republic. Sustainability 2021, 13, 12452. https://doi.org/10.3390/ su132212452

Academic Editor: Pierfrancesco De Paola

Received: 22 September 2021

Accepted: 8 November 2021

Published: 11 November 2021

Publisher's Note: MDPI stays neutral with regard to jurisdictional claims in published maps and institutional affiliations.

Copyright: (c) 2021 by the authors. Licensee MDPI, Basel, Switzerland. This article is an open access article distributed under the terms and conditions of the Creative Commons Attribution (CC BY) license (https:/ / creativecommons.org/licenses/by/ $4.0 /)$.

\begin{abstract}
The issue of environmental risk assessment currently deserves great attention. In order to protect the environment, maintain healthy living conditions, and prevent environmental damage, the member states of the European Union have adopted a Directive of the European Parliament and of the Council on environmental liability with regard to the prevention and remedying of environmental damage. The directive classifies two types of operators with different liability regimes for environmental damage, namely, the regime with no-fault (strict) liability and liability for fault. With the adoption of the directive, among experts, operators and the general public have posed questions about how to assess the risk of environmental damage. At present, there is still no uniform procedure for assessing environmental risks, which would create a comprehensive methodological framework for assessment for this type of risk. Due to the non-existent risk assessment methodology for operators with strict liability regimes and the lack of a systematic search for risk sources, a risk assessment procedure is proposed that provides guidance in a sequence of several steps on how to implement the obligations arising from the adopted Environmental Liability Directive. The proposed procedure was verified on a specific operator with a strict liability regime. The environmental risk analysis performed through the proposed procedure provided information on possible operational problems and verified its applicability. Last but not least, the use of the proposed procedure makes it possible to identify serious sources of risk and to establish necessary preventive measures to prevent the occurrence of environmental damage.
\end{abstract}

Keywords: diesel fuel; emergency scenario; environmental risk assessment; environmental damage; filling station; petrol; source of risk

\section{Introduction}

Major accidents usually cause disruptions to the life of any society, in particular through their consequences for life, human health, property, and the environment. Moreover, major accidents can cause both direct damage to the exposed population and vast damage to the environment that, as a result, might indirectly affect the population by the contamination of land, surface water, and groundwater [1].

An environmental risk assessment caused by the activities of companies is an important part of the safety documentation required by the applicable legislation in the EU member states. The number of industrial accidents with negative consequences for human life and health and the environment accounts for the salience of this issue. Examples are the dioxin leak in Seveso (1976), the explosion of a chemical plant in Bhopal (1984), and the cyanide leak from a mine in Baia Mare (2000), to mention a few.

The rapid growth of urbanization has created greater demand for vehicles, which results in more fuel consumption, which, in turn, leads to the need for building more 
petrol stations. A filling station (FS) is a place catering to the fuel need [2]. In recent years, many filling stations have been built within urban areas, close to residential areas, and in protected landscape areas. Filling stations are facilities that often contain, store, and handle large quantities of hazardous materials, mainly gasoline and diesel. In addition, some petrol stations carry specialty fuels such as liquefied petroleum gas (LPG), natural gas, hydrogen, or biodiesel. Therefore, an emergency event at a petrol station might lead to significant human losses and potentially cause damage to the environment.

Generally, a filling station is, to a certain extent, one of the most widely distributed hazardous sites. Some case studies showed that many previous accidents occurred in petrol stations, resulting in property losses and casualties [3].

In particular, direct risk assessment for the population resulting from emergency events-accidents (fires, explosions, leaks of hazardous substances) has attracted great attention recently. Existing studies dealt primarily with negative consequences for life, secondly with the health of the population [4-8], and thirdly with the assessment of the safety of the filling stations [9-11]. On the contrary, less exploration into the quantitative assessment of the risk due to the environmental consequences of accidents was carried out. According Bonvicini et al., wide attention has been paid to date to the assessment of the direct risk to the population from major accidents (fires, explosions, toxic releases). Less work has been devoted to the quantitative assessment of the risk from the environmental consequences of major accidents. [1].

The above analysis of the scientific literature and studies shows that more and more studies have now been carried out to assess the risks and determine the negative consequences for humans [5-9]. However, in the case of service stations, there is limited literature aimed at determining the negative effects on the environment. Environmental protection constitutes one of the pivotal factors for maintaining healthy living conditions. The EU's goal in this area is to halt the loss of biodiversity, prevent the deterioration of water quality, reduce water supplies, and protect the land for present and future generations. For this reason, the member states of the European Union have committed themselves to the prevention and mitigation of environmental damage in case such an event occurs.

The environmental liability regimes within the EU member states differs in terms of the extent of the environmental damage they handle and in respect to the mitigation requirements. In 2004, the European Union undertook steps to introduce a more uniform regime for the prevention and remedying of environmental damage by adopting Directive 2004/35/EC on environmental liability with regard to the prevention and remedying of environmental damage. The legislation introduced a comprehensive liability regime for environmental damage explicitly for the first time within the EU [12]. The Directive was issued on 21 April 2004.

In conjunction with the adoption of the Environmental Liability Directive (Directive 2004/35/EC), the issue of environmental liability became a much-discussed topic worldwide, and various publications from several perspectives assessing environmental liability appeared [13-21]. According to Lee, "Environmental liability as a part of administrative law is increasingly significant and controversial, and the proliferation of schemes creates difficult legal problems" [13]. Sikorova et al. stated, "The EU Member States employ different approaches and schemes to satisfy the requirements of Environmental Liability Directive in the issue environmental risk assessment" [12].

Pouikli stated, "However, the efficient implementation of this sui generis legal framework regarding prevention and remediation of the environmental damage has been proved really problematic at the European level due to legal discrepancies and technical deficiencies. Eleven years after the adoption of the Environmental liability Directive (ELD) particular interpretation issues concerning the determination of the responsible operator, the application of the optional provision of the ELD, the extent of the exceptions, the financial security, and the role of the competent authorities remain unanswered" [14].

The literature review revealed the positive impacts of the Environmental Liability Directive towards environmental protection, but the lack of a uniform framework seems to 
limit its performance [16], especially the lack of a holistic approach concerning environmental liability [19].

Accordingly, Goisis and Stefani summarized this development as follows: "Recent jurisprudential developments conferred new impulse to the debate revolving around the scope and significance of the polluter-pays principle" [22].

Thus, although the Environmental Liability Directive undoubtedly is an important step in the harmonization of environmental liability in the European Union, the Environmental Liability Directive has not been implemented in the member states in a uniform way. It should be noted that this could have an impact on the approach to be taken in case of transboundary incidents and possibly makes it more difficult for the public authorities to successfully deal with such cases [23].

The Environmental Liability Directive, with regard to the prevention and remedying of environmental damage, differentiates two types of operators to which the legislation applies. The first group includes operators performing occupational activities that pose a risk for human health or the environment. The second group is made up of operators performing any other occupational activities causing potential environmental damage that protected species and natural habitats of European importance are exposed to, but only at their fault (violation of the law).

The different regime of liability for environmental damage applies to each of these groups (see Figure 1). In the case of operators belonging to the first group, a system of no-fault (strict) liability applies. This means that in order for the operator to be held liable for damage to land, water, protected species, and natural habitats of European importance, no fault has to be established. In the case that the operators belong to the second group, a system of liability for fault applies, and the operator might be held liable only if he/she is at fault or found negligent. Nevertheless, these operators might be held liable solely for damage to protected species and natural habitats of European importance [24].

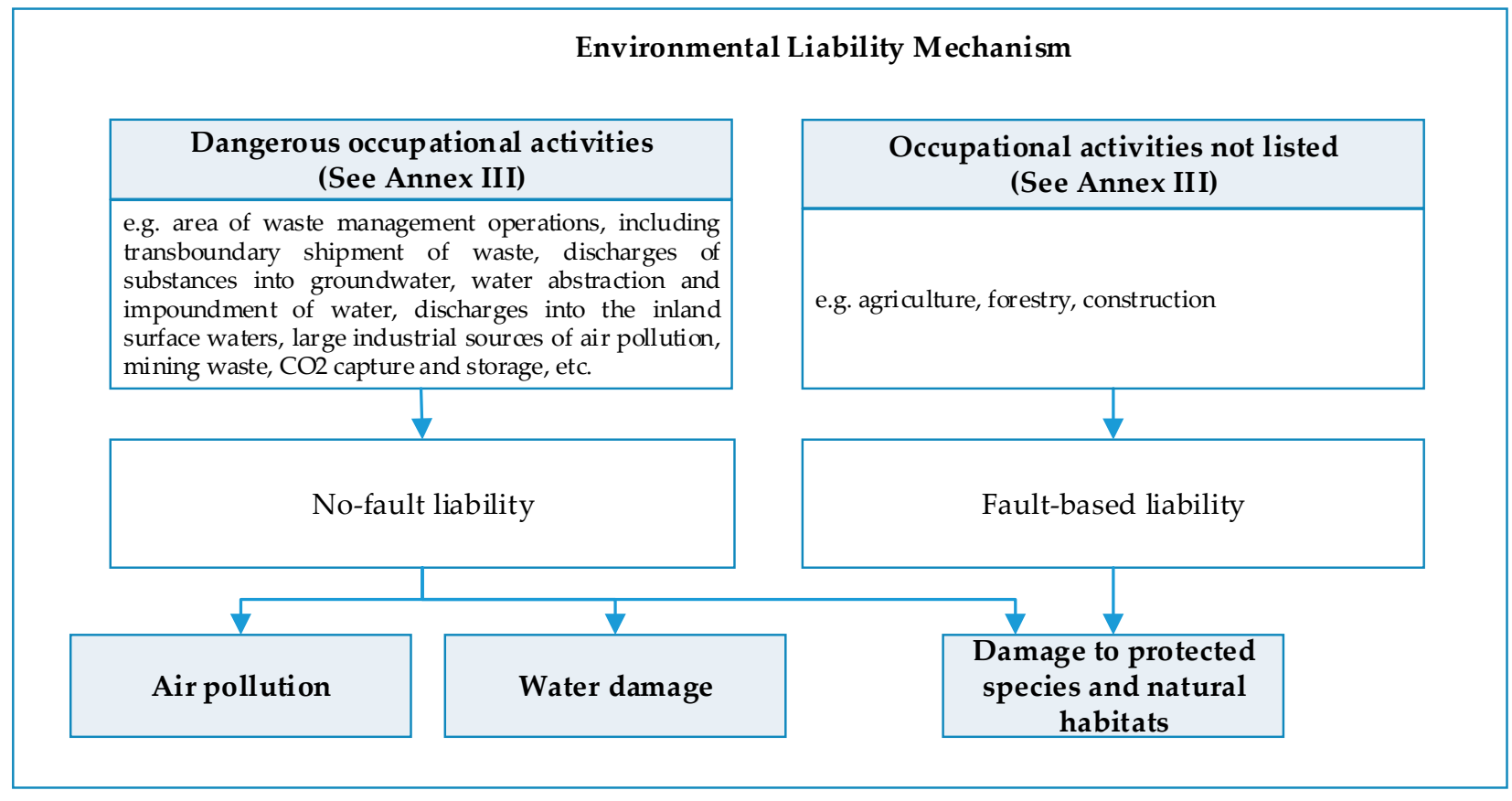

Figure 1. Environmental liability mechanism (source: modified by [24]).

The issued directive comprises various operators, including filling stations (hereinafter referred to as FS). An FS is undoubtedly an important facility, but it is reported that it has high potential for degradation of natural resources, pollution problems, environmental degradation, and hydrological, geological, and socio-economic hazards, and therefore the site selection of such facilities is an essential problem $[25,26]$. In many cases, FSs are located 
in residential areas, close to watercourses and protected areas. They are not seen as a significant source of risk during normal operation. Statistics show that the likelihood of an emergency is, in most respects, low, but the effects of such an event are unacceptable and might cause significant damage to the environment, such as protected species and natural habitats, water, and land.

Considering the mentioned legislation, filling station operators are subject to strict, no-fault liability. The operators are obliged to prevent the threat of environmental damage by taking and implementing preventive measures. Furthermore, in case of environmental damage they must take and implement corrective measures. Operators should, in the first place, perform an environmental risk analysis and assess whether their activities are believed to be susceptible to causing environmental damage (e.g., whether they are located in an area with protected species and natural habitats of European importance, etc.).

For the needs of our case study, the authors chose a filling station located near a watercourse. For the most part, an emergency associated with an eventual fuel spill outside of an emergency tank could have a negative impact on the environment.

Therefore, the paper aims to fill the existing gap in the operators' knowledge in the application of the polluter-pays principle. Besides that, it provides filling station operators with simple instructions on how to implement a must arising from the Environmental Liability Directive, including the procedure for carrying out an environmental risk analysis.

\section{Materials and Methods}

Currently, no uniform approach towards environmental risk assessment exists in EU countries. The current legislation only stipulates general requirements for safety documentation; however, it does not set requirements or recommendations for the use of individual risk assessment methods. Approaches to environmental risk assessment differ essentially in the methods developed in individual EU member states.

\subsection{Approaches to an Environmental Risk Assessment}

The approach to an environmental risk assessment is based on a societal risk assessment process [27]. However, at present, a uniform approach to an environmental risk assessment is not precisely defined, since the latter is a uniform methodological approach to the assessment of this risk [28]. Hence, the approaches to the societal risk assessment constitute a model for environmental risk assessment. The procedure for assessing societal and environmental risks is, as a rule, similar. More precisely, the procedure relies on the principle of determining the acceptability of a risk based on the ratio of the frequency of occurrence of an event and the fatal consequences of that event. The primary difference lies in the assessed subject. To put it in a nutshell, although the subject of assessment is human as the only biological species in the case of societal risk, we are convinced of the need to assess the probability of adverse effects on plants, animals, and parts of the environment occurring in real ecosystems of individual components in the case of environmental risks [26].

The approaches to an environmental risk assessment differ mainly according to the methods developed in individual EU member states. The following section discusses a range of approaches to environmental risk assessment in selected EU countries, England, and the USA.

\subsubsection{The Netherlands}

In the Netherlands, Proteus modeling software is frequently used for risk analysis, which allows the impacts of large-scale accidental releases of hazardous substances on surface waters to be modeled. As far as the methodology used is concerned, it comprises two models, VERIS and RISAM. The VERIS model evaluates the risk based on a questionnaire. The RISAM model analyzes the data from industrial equipment [29].

The risk assessment in the Netherlands is established based on the so-called QMFT (Quantity, Mass, Frequency, Time) factors (hydraulic flow Q, amount of chemicals M, fre- 
quency $\mathrm{F}$, time range of leakage $\mathrm{T}$ ). This procedure takes into account the general situation, and, for this reason, it is necessary to consider certain conditions concerning the technical condition or technological procedures related to the case. For local specifications, the so-called "local correction factors" identify the technical condition of safety management. Accordingly, technical correction factors describe, for example, the effect of alarms, automatic shutdown, and robustness of construction materials with regard to both the quantity and the probability of hazardous chemical leakage (extensive databases containing the causes of accidents are sources of data for these factors). An inevitable part of the risk assessment is a questionnaire that considers the influence of the level of industrial equipment, relevant accident scenarios, and, in addition, the quality of safety management. The questionnaire contains 41 questions divided into 5 areas that might impact the occurrence and course of an accident.

The result of the assessment is a comprehensive report identifying first, the extent of accidental effects; second, the impact of leaked substances on the environment; third, the number of toxic units; and finally, the impact of the effectiveness of the safety features.

\subsubsection{Sweden}

In the Swedish approach, the establishment of the so-called EAI (EnvironmentAccident Index) plays a pivotal role. The methodology was first put forward in 1995 as a tool for [30]:

- Preventive planning;

- Examination of environmental risks;

- Identification and classification of risk areas.

It is intended for the use by the relevant administrative authorities, rescue services, and industry.

The EAI index calculates the acute toxicity values of a given substance (LC50 / EC50), the stored or transported amount of the substance, its viscosity, and its solubility in water, as well as the properties of the environment into which the substance escapes.

The EAI (Environment-Accident Index) is a tool for the identification and evaluation released substances that are hazardous to the environment. The values of the EAI determine the method of further evaluation, i.e., which of the analyzed units requires a more detailed analysis of environmental risks. The EAI method includes both a combination of environmental characteristics (soil and water) and chemical properties (toxicity, density...). Scientists calculate the EAI index based on three factors: acute aquatic toxicity (Tox), stored/transported amount (Am), and substance and environmental properties (viscosity, solubility, environmental properties). More precisely, they calculate the third factor as a function of the viscosity of the leaked substance, the solubility of the leaked substance, and the properties of the environment (ability of soil penetration, depth and slope of groundwater). The formula for calculating the EAI is as follows:

$$
\text { EAI index }=\text { To } \times \text { Am } \times(\text { Con }+ \text { Sol }+ \text { Sur })
$$

where:

Tox-acute toxicity to aquatic organisms $[\mathrm{mg} / \mathrm{L}]$;

Am-stored/transported quantity [t];

Con-viscosity of the substance [cSt];

Sol—solubility [wt.\%];

Sur-properties of the environment (distance to the nearest water flow, groundwater depth, groundwater gradient, soil thickness above groundwater).

Based on the EAI calculation, a classification scale was devised by outlining other procedures (see Table 1). 
Table 1. Classification scale for the EAI method [30].

\begin{tabular}{|c|c|c|}
\hline EAI Value & $\begin{array}{l}\text { Proposed } \\
\text { Procedure }\end{array}$ & Comment \\
\hline $1-100$ & Input hazard analysis (HA) & $\begin{array}{l}\text { The study covers the properties of substances related to mobility, degradation, } \\
\text { toxicity, classification, etc. }\end{array}$ \\
\hline $100-500$ & $\begin{array}{l}\text { Initial hazard analysis }(\mathrm{HA})+ \\
\text { initial environmental risk } \\
\text { assessment (ERA) }\end{array}$ & $\begin{array}{l}\text { The study includes an extended form of HA (data on the site where the } \\
\text { schematic substance is handled) and the determination of the affinity for a } \\
\text { particular environmental compartment. }\end{array}$ \\
\hline$>500$ & $\begin{array}{l}\text { Extended environmental risk } \\
\text { assessment (ERA) }\end{array}$ & $\begin{array}{l}\text { The study includes a comparison of the predicted watercourse concentration } \\
\text { (PEC) with concentrations without a negative effect on the watercourse } \\
\text { (PNEC), the determination of emergency scenarios, and the modeling of the } \\
\text { impact of the watercourse. This part of the evaluation also includes an } \\
\text { evaluation of the impact of a hazardous substance on groundwater. }\end{array}$ \\
\hline
\end{tabular}

\subsubsection{The Czech Republic}

In order to assess environmental risks, the index methods $\mathrm{H} \& \mathrm{~V}$ and ENVITech03 are recommended by the Ministry of the Environment of the Czech Republic [31].

The H\&V index method assesses the severity of an accident involving a dangerous substance in the environment. The severity of the accident is scored by indices in which hazard indices of the substance and environmental vulnerability indices alongside their separated determination take on a key role. In conjunction with them, the resulting severity of an accident emerges as a combination of the hazard index of the substance, the environmental vulnerability index, and the amount of the substance leaked into the environmental component during the accident. Finally, the output of the method is a risk matrix according to which its acceptability is assessed.

The H\&V index methodology is primarily intended for the assessment of short-term releases of hazardous substances into the environment not exceeding hours or days in their time horizon. Due to this fact, the evaluation of long-term releases of previous ecological burdens into the environment is not feasible with the methodological approach. Thus, the method does not, in theory, apply to the biodegradation of substances in environmental components, as they are not relevant to massive releases of hazardous substances into the environment. Furthermore, the method also does not address synergies or domino effects. Undoubtedly, the assessment of the impacts of accidents involving a dangerous substance on the environment cannot be carried out independently without knowledge of the risk analysis outputs of a major accident. Let us now turn to the first step establishing the criteria for the acceptability of a major accident (severity and probability/frequency). These criteria must be set before the risk analysis itself and arise on the basis of social consensus, law, or by the company on the basis of its internal standards and priorities. Second, the risk assessment requires an analysis of the risks of a major accident, which, among others, reveals the possible threat to the environmental components. If a major accident does not threaten the environmental components on the whole, assessors skip the evaluation. Otherwise, the probability of leakage of the dangerous substance into the environment is involved in the risk analysis section.

ISATech, Ltd. devised the Envitech methodology of environmental vulnerability analysis [32]. The principle of this methodology is the determination of two parameters, A (characterizes the evaluated component of the environment) and B (includes the outputs of technological analyses of risk - probability).

The term "environmental vulnerability" expresses the relationship between the probability of an accidental leak and the ability to reduce the range and extent of accidental manifestations. The ratio between indices $\mathrm{A}$ and $\mathrm{B}$ expresses a five-level risk classification (very low vulnerability to very high vulnerability).

The result of the environmental vulnerability assessment is the assignment of one of the five classification classes, which, however, does not handle the amount of leaked hazardous substance. 


\subsubsection{The Slovak Republic}

Within the conditions of the Slovak Republic, safety engineers promote the primary classification approach when assessing environmental risks. In the next step, significant issues are tackled. The purpose of the initial assessment is, in general, to offer important insights regarding whether there are sources, equipment, or technologies for which a detailed environmental risk assessment is required or whether an initial assessment is sufficient.

Accordingly, simpler applicable methods are recommended for the initial assessment, such as index or screening methods (e.g., EAI, risk index Z, Environmental Harm Index), whose results are ultimately presented as risk indices (levels) [33]. On the contrary, more demanding methods are recommended to perform a similar analysis for sources with the worst indices. This approach sets out to reduce the number of facilities in the company assessed in detail in order to simplify risk analysis on the whole and to attract assessors' attention to the most serious sources of risk.

Nevertheless, experts from various fields conduct a detailed assessment when recommended. Their expertise includes the prevention of serious industrial accidents, waste management, nature and landscape protection, geology and hydrogeology, safety and health protection, etc. In line with the detailed risk assessment, they must apply vulnerability analyses (calculation, quantification of the relevant damage) with regard to the probability of occurrence of the analyzed adverse event.

\subsubsection{United Kingdom}

The environmental risk assessment methodology used in the United Kingdom is very comprehensive. It features first, a systematic approach to identifying sources of risk; second, determining the probability and severity of the risks; and third, an acceptability assessment of the risk [34].

In line with this, an environmental risk assessment is the formal process of hazard consequence evaluation as well as its probability. The assessment itself, for the most part, involves four stages:

1. Identifying the hazard(s);

2. Assessing the potential consequences;

3. Assessing the probability of the consequences;

4. Characterizing the risk and uncertainty.

The security engineers apply the approach based on the existing situations with possible hazard to the environment in which, in turn, the assessment of the risk they pose must be scrutinized. However, it should be noted that in cases of animal health risk assessment, hazard identification is part of risk analysis and in no case the official assessment process [35].

\subsubsection{The USA}

In the USA, the United States Environmental Protection Agency (EPA) covers environmental protection. According to EPA [36], "ecological risk assessment is the process for evaluating how likely it is that the environment may be impacted as a result of exposure to one or more environmental stressors such as chemicals, land change, disease, invasive species and climate change".

An ecological risk assessment includes three phases:

- Problem formulation;

- Analysis;

- Risk characterization.

First, problem formulation focuses on gathering information that helps to identify what poses a risk for plants and animals and what needs protection. Second, analysis is the determination of what risk plants and animals face, to what degree they are exposed, and whether that level of exposure is likely or not to cause harmful ecological effects. Third, risk 
characterization includes two major components: risk estimation and risk description. Risk estimation comprises exposure profiles and exposure-effects. Risk description provides salient data for interpreting risk results. Furthermore, it identifies a level for harmful effects on the plants and animals concerned. The risk assessment scheme is shown in Figure 2.

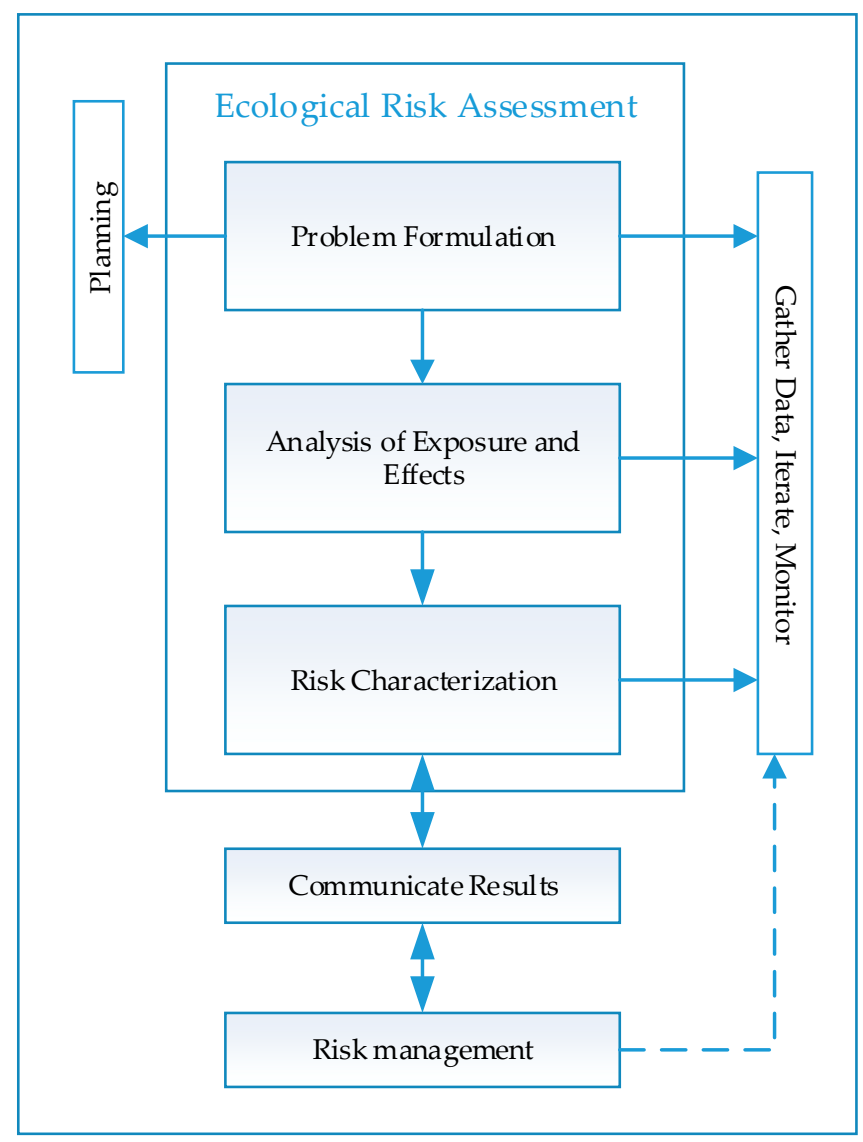

Figure 2. Phases of ecological risk assessment (source: adapted [37]).

\subsubsection{Evaluation of Methodologies and Approaches to Environmental Risk Assessment}

As already mentioned, currently no uniform view exists on the assessment of environmental risks. Index methods unfortunately do not provide us a holistic view of the risk [38]. They usually draw on previous risk analyses and must be supplemented by a subsequent quantitative assessment of environmental risks.

In a similar vein, the Swedish approach can be traced to the determination of an index as well. Nevertheless, the input parameters, including both the properties of substances and the environmental properties, make it feasible to obtain values (Environmental Accident Index), with a value establishing the potential threat to the unit.

The Dutch Proteus method is used to obtain a quantitative output, or volume, of contaminated surface water for an accident scenario identified by other methods.

The approach to environmental risk assessment in the Czech Republic and the Slovak Republic is similar. The Ministries of the Environment recommend the use of index methods in the assessment procedure. Within the context of the Slovak Republic, the Ministry recommends conducting a similar analysis by means of more demanding methods for sources with the worst indices.

The USA's and England's methodologies appear to be among the most comprehensive approach to environmental risk assessment. As for the proposed environmental risk assessment procedure, it puts forward the identification of sources of risk and concludes with the assessment of the acceptability of environmental risks. It utilizes the outputs of 
detailed analyses for determined accidental leaks as well, thus moving it into a sort of methodology based on engineering knowledge and procedures.

\subsection{Design of a Methodological Procedure for Environmental Risk Assessment}

The procedure for environmental risk assessment was designed in accordance with the directive on environmental liability with regard to the prevention and remedying of environmental damage for operators who are covered by the strict, no-fault liability regime for environmental damage under the directive (see Figure 1). The risk assessment procedures constitute the following steps to be carried out:

1. Determination of the type of liability for the environmental damage (in concordance with the directive).

2. Identification of sources of risk and determination of emergency scenarios.

3. Initial assessment of emergency scenarios (by index methods).

4. Detailed assessment of major emergency scenarios (based on the results of the initial assessment).

The initial step is to determine the type of liability for environmental damage according to the type of occupational activity of the operator, which is categorized in Directive 2004/35/EC on environmental liability with regard to the prevention and remedying of environmental damage.

The next step is to identify emergency scenarios conducted by means of utilizing the data of both operational activities and technological processes in the company, the location of the company, a list of hazardous substances, their location in facilities, information on the quantities of hazardous substances present in the company, and finally, information on the environment.

The third step is an initial risk assessment processed in order to identify the sources of risk. For its implementation, a comparison of the most frequently used methods was performed (see Section 2.1.). For the purpose of risk source assessment and the utilization of simpler methods, the so-called index, or screening methods, is proposed. Risk indices (levels) form as a result of risk source assessment. Such an approach sets out to reduce the number of facilities within the company assessed in detail. In addition, it simplifies the whole risk analysis and, finally, it focuses attention on the most serious sources of risk $[39,40]$. The method selected for the initial assessment was the EAI index.

The final step involves a detailed risk assessment and a proposal for measurements to prevent an emergency for facilities being assessed as significant sources of risk. As far as the detailed assessment procedures are concerned, as a rule, they require in-depth analysis by more sophisticated methods through a team of experts or specialists.

\subsection{Characteristics of the Filling Station Facility}

The case study's writers carried out an environmental risk assessment associated with the operation of the filling station at a selected filling station facility. In conjunction with the request of the operator to maintain the anonymity of the filling station, the paper will neither publish data such as the name of the company nor mention a detailed identification of the location of the investigated facility.

\subsubsection{An Identification of the Subject and Its Activity}

The filling station facility is situated in the cadastral district of a municipality (town). The filling station area is a part of the industrial-commercial zone in the town residential area with residential buildings and adjacent streets, located near the watercourse of a river.

Turning now to the premises of the fuel FS, it comprises the main buildings as follows: the service facility, the roofing of dispensing points, the washing line, and the storage of tanks. The operating facility and the object of the fuel FS provide all the required functions for unloading, filling, storing, and dispensing fuels by means of individual parts of technological equipment. 
The technological and operating facility of the fuel FS provides the following activities and services:

- Unloading of fuels from tanks into storage tanks;

- Dispensing of fuels into the tanks of customers' vehicles alone;

- Control of fuel dispensing from the service room of the filling station;

- Additional functions (washing vehicles in the washing line, inflating tires for passenger cars, dry cleaning of vehicle interiors-vacuuming).

At a total of six dispensing points, fuel is dispensed to customers in the following range: diesel (diesel fuel) $-45 \mathrm{~m}^{3}$ of stored volume and petrol "Natural 95 " $-45 \mathrm{~m}^{3}$ of stored volume.

The unloading of fuels is performed at the unloading station point at the unloading shaft (situated on an island of the outer dispenser, see Figure 3). The unloading shaft is situated on the edge of the dispenser point roof located on the side of the public road, whereas the tank set (tractor + semi-trailer) partially extends into the fuel filling station.

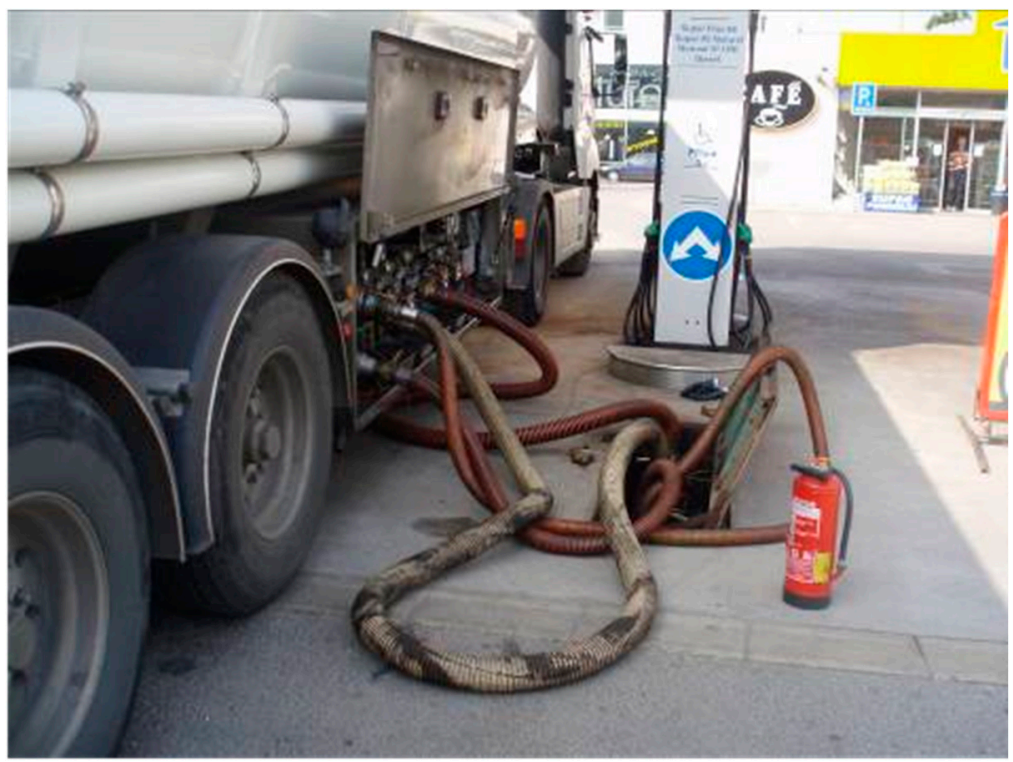

Figure 3. Unloading of fuels (source: authors).

\subsubsection{An Identification of the Sources of Risk and Their Location}

Petrol and diesel (liquid hydrocarbons) pose the main sources of risk, and are stored and handled (while unloading and dispensing to customers) at the fuel FS facility. In the event of an uncontrollable fuel spill, these substances might contaminate individual components of the environment.

The road tankers import the substances listed in Table 2 into the FS facility and they are stored in underground tanks.

Table 2. Hazardous substances present at the FS facility.

\begin{tabular}{ccccc}
\hline $\begin{array}{c}\text { Hazardous } \\
\text { Substance }\end{array}$ & Equipment & Quantity (kg) & $\begin{array}{c}\text { Physical Form of the } \\
\text { Substance }\end{array}$ & Classification H-Phrases \\
\hline \multirow{2}{*}{ Diesel fuel } & Storage tank & 39,100 & Liquid & H226 (Cat. 3); H351 (Cat. 2); H332 (Cat. 4); H304 (Cat. 1); H315 \\
Tank & 30,505 & Liquid & (Cat. 2); H373 (Cat. 2); H411 (Cat.2) \\
Petrol & Storage tank & 36,800 & Liquid & H224 (Cat. 1); H304 (Cat. 1); H315 (Cat.2); H361 (Cat. 2); H340 \\
“Natural 95” & Tank & 27,978 & Liquid & (muta 1B); H350 (carc. 1B); H336 STOT Single exp. 3; H411 (Cat.2) \\
\hline
\end{tabular}

The technological process of fuel unloading is associated with the risk that arises from the following facts: 
- A large amount of hazardous substances is unloaded from the tank vehicle into the storage tanks and, at the same time, recovered gases are discharged from the storage tanks into the tanks;

- The handling area for the unloading of fuels is not fenced, i.e., it is accessible to unauthorized persons who may interfere with the unloading of fuels;

- There is a risk of fuel spillage;

- There is a risk of the storage tanks being overfilled.

\subsection{An Identification of Emergency Scenarios}

Penetration of hazardous substances directly into groundwater and subsequently into surface waters might happen, especially in the case of a fuel spill over unpaved terrain [41]. In a similar vein, workers (and customers) handle the fuels in the process of unloading and dispensing them within the premises of the fuel FS. Real cases in which fuel spills might occur are given in Table 3.

Table 3. Emergency scenarios.

\begin{tabular}{|c|c|c|c|c|}
\hline & $\begin{array}{l}\text { Emergency } \\
\text { Scenario }\end{array}$ & Type of Spill & Cause of Spill & Consequences of the Spill \\
\hline \multirow[t]{2}{*}{1.} & \multirow[t]{2}{*}{$\begin{array}{l}\text { Fuel spill during } \\
\text { unloading }\end{array}$} & $\begin{array}{c}\text { One-time leakage of the entire } \\
\text { transported quantity or only } \\
\text { one chamber }\end{array}$ & $\begin{array}{l}\text { Damage to the integrity of the } \\
\text { tank shell }\end{array}$ & $\begin{array}{l}\text { Leaked fuel will get outside the } \\
\text { paved area. }\end{array}$ \\
\hline & & $\begin{array}{l}\text { Continuous leakage of } \\
\text { unloaded fuels }\end{array}$ & $\begin{array}{l}\text { Rupture of the unloading hose, } \\
\text { or its incorrect installation on } \\
\text { the connections with the } \\
\text { unloading pipe or the tank; } \\
\text { overfilling of tanks }\end{array}$ & $\begin{array}{l}\text { Leaked fuel will not spill outside } \\
\text { the paved area; it will be caught in } \\
\text { the emergency tank. }\end{array}$ \\
\hline 2. & $\begin{array}{l}\text { Fuel spill from the } \\
\text { storage tanks }\end{array}$ & Continuous & Tank leak & $\begin{array}{l}\text { Leaked fuel will not spill outside } \\
\text { the paved area; it will be caught in } \\
\text { the emergency tank. }\end{array}$ \\
\hline 3. & $\begin{array}{l}\text { Fuel spill from the } \\
\text { storage tanks }\end{array}$ & Continuous & $\begin{array}{l}\text { Rupture or leakage of the } \\
\text { transport line }\end{array}$ & $\begin{array}{l}\text { Leaked fuel will not spill outside } \\
\text { the paved area; it will be caught in } \\
\text { the emergency tank. }\end{array}$ \\
\hline 4. & $\begin{array}{l}\text { Fuel spill from } \\
\text { dispensers during } \\
\text { refueling }\end{array}$ & Continuous & $\begin{array}{l}\text { Damage to the dispenser or } \\
\text { dispensing guns when } \\
\text { refueling customers' vehicles }\end{array}$ & $\begin{array}{l}\text { Leaked fuel will not spill outside } \\
\text { the paved area; it will be caught in } \\
\text { the emergency tank. }\end{array}$ \\
\hline
\end{tabular}

\section{Results}

The authors conducted the environmental risk assessment resulting from the operation of the FS using the EAI method. The Ministry of the Environment of the Slovak Republic recommends this method for our purposes, in conjunction with the valid legislation in this area. According to the international regulations for the transport of dangerous goods (ADR), the fuels are classified in the third hazard class, that is, flammable liquids. Therefore, they were subject to an environmental risk assessment.

\section{Results of the Assessment of Emergency Scenarios}

In general, workers (and customers) carry out the process of handling fuels (unloading, dispensing of fuel) and their storage is on a paved surface. Besides, any leakage of a small amount of fuel onto the handling area is captured in the fuel trap in the emergency tank. Typically, the pipe of the fuel trap is closed using an emergency closure, which prevents fuel from leaking into the public sewer. The emergency shut-off valve works automatically on the principle of a float body, which closes the drainpipe and redirects the contents of the fuel trap to the emergency tank when the surface reaches a defined amount of oil substances [41]. With the help of the built-in device intended for the separation of oil substances, the oil substances can be sucked out at any time. Finally, fuel residues that 
have not run off the handling area or do not have the option of being drained are removed using absorbent material (perlite, vapex sorbent, sawdust) [42].

In the event of a one-time leakage of a large amount of fuel (e.g., leakage of the entire amount of fuel from the tank during unloading), the leaked fuel spilling outside the handling (paved) area might cause contamination of the subsoil and enter the rain sewer.

When trying to identify the emergency scenarios, we considered the amount of fuel spilled outside the paved area. As a result, fuel spills (of diesel fuel and petrol) during unloading refer to significant emergency scenarios. For this reason, the Environmental Risk Indices were established only for the leakage of diesel fuel and petrol in the unloading process for the entire volume of the tank and for the volume of one tank chamber.

In terms of the characteristics of the environment, the following parameters were identified for the calculation of the EAI:

- Distance to the nearest watercourse (DNW): approx. $60 \mathrm{~m}$;

- Groundwater depth (DGS): 2-5 m;

- Slope of the groundwater level: the groundwater level tends to have water flow;

- Strength and character of the soil above groundwater: concrete area.

Table 4 presents the results of the index calculation for the selected emergency scenarios: petrol/diesel fuel spill from the tank.

Table 4. EAI for the selected scenarios.

\begin{tabular}{|c|c|c|c|c|c|c|c|c|}
\hline Hazardous Substance & Equipment & Quantity (kg) & Tox & Am & Con & Sol & Sur & EAI \\
\hline \multirow{2}{*}{ Diesel fuel } & Tank (the entire volume) & 30,505 & 4 & 5 & 4 & 1 & 5 & 300 \\
\hline & Tank (1 chamber) & 4136 & 4 & 3 & 4 & 1 & 5 & 120 \\
\hline \multirow{2}{*}{ Petrol } & Tank (the entire volume) & 27,978 & 6 & 5 & 4 & 1 & 5 & 200 \\
\hline & Tank 1 (chamber) & 3525 & 6 & 3 & 4 & 1 & 5 & 180 \\
\hline
\end{tabular}

In absolute terms, if the EAI value is greater than 100, a detailed risk assessment must be carried out by qualified personnel [43].

\section{Discussion}

The presented manuscript deals with the issue of environmental risk assessment by operators who perform work activities considered to be risky under the applicable legislation in the field of environmental responsibility. The aim of the authors was to point out that there is currently no uniform systematic procedure for the quantitative assessment of this risk for operators who are subject to a system of strict liability for environmental damage. In the area of environmental liability risk assessment aimed at quantifying environmental risks under the Environmental Liability Directive, not much attention has been paid so far. A similar study to assess the environmental liability risk assessment was performed by Good et al. [44]. However, it was conducted for operation in accordance with EPA guidelines. Based on the above facts, a methodological procedure for environmental risk assessment was proposed. The proposed procedure allows operators with strict liability for environmental damage to implement the process of environmental risk assessment in a logical sequence of several steps.

The proposed procedure is based on the initial assessment of environmental risks using index methods, in which operators, by completing a set of tables, identify scenarios with the potential for environmental damage in relation to their work or permitted activities. Relying on the results of the initial assessment, operators will be able to decide whether this assessment is sufficient or whether a more detailed risk analysis will be required depending on the scenarios they experience. Our results also shed light on the fact that detailed assessment procedures require a deeper analysis, the implementation of which requires a team of experts and specialists.

Referring to the assessment of environmental risk sources resulting from the operation of the fuel filling station discussed above, the authors state that from the point of view of 
environmental protection, unloading fuel from a tank truck into storage tanks appears to be problematic at the FS facility. This statement by the authors is also confirmed by the results of studies aimed at determining the sources of risks and emergency scenarios in FS facilities. This was demonstrated in studies by Bonvici et al. [1], Ma and Huang [9], Mirae et al. [45], Tahmid et al. [46], and Tang et al. [47].

The event of an accidental fuel spill while unloading from the tank to the storage tanks might endanger the quality of the environment (groundwater and surface water, soil). Drawing on both the calculated values of the EAI as well as according to the EAI methodology (value in the range of 100-500) [30], our recommendation is fora detailed risk assessment to be conducted by qualified professionals.

Author Contributions: Conceptualization, K.M. and K.K..; methodology, K.M.; validation, T.L.; formal analysis, K.P.; investigation, K.M., K.K. and T.L.; resources, K.M. and K.P.; data curation, K.K. and T.L.; writing — original draft preparation, K.M., K.K. and T.L.; writing—review and editing, K.K., K.M. and T.L.; visualization, K.K.; supervision, T.L.; project administration, K.M.; funding acquisition, K.K. All authors have read and agreed to the published version of the manuscript.

Funding: The article was supported by the Ministry of Education, Science, Research and Sport of the Slovak Republic and the Slovak Research and Development Agency, grant number APVV-20-0457, Monitoring and Tracing of Movement and Contacts of Persons in Medical Facilities.

Institutional Review Board Statement: Not applicable.

Informed Consent Statement: Not applicable.

Data Availability Statement: The data presented in this study are available on request from the corresponding author.

Conflicts of Interest: The authors declare no conflict of interest.

\section{References}

1. Bonvicini, S.; Antonioni, G.; Cozzani, V. Assessment of the risk related to environmental damage following major accidents in onshore pipelines. J. Loss Prev. Process. Ind. 2018, 56, 505-516. [CrossRef]

2. Khahro, S.H.; Matori, A.N.; Chandio, I.A.; Talpur, M.H. Land Suitability Analysis for Installing New Petrol Filling Stations Using GIS. Procedia Eng. 2018, 23, 28-36. [CrossRef]

3. Liu, D.; Xu, Z.; Fan, C.; Zhou, Y. Regional evaluation of fire apparatus requirements for petrol stations based on travel times. Proc. Saf. Environ. Prot. 2020, 135, 350-363. [CrossRef]

4. Terrés, I.M.M.; Miñarro, M.D.; Ferradas, E.G.; Caracena, A.B.; Rico, J.B. Assessing the impact of petrol stations on their immediate surroundings. J. Environ. Manag. 2010, 91, 2754-2762. [CrossRef] [PubMed]

5. Maksoud, H.A.A.; Elharrif, M.G.; Mahfouz, M.K.; Omnia, M.A.; Abdullah, M.H.; Eltabey, M.E. Biochemical study on occupational inhalation of benzene vapours in petrol station. Resp. Med. Case Rep. 2019, 27, 100836.

6. Makka, K.; Kampova, K.; Lovecek, T.; Bernatik, A.; Rehak, D.; Ondrejka, R. Prevention and mitigation of injuries and damages arising from the activity of subliminal enterprises: A case study in Slovakia. J. Loss Prev. Process. Ind. 2021, 70, 104410. [CrossRef]

7. Geraldino, B.R.; Nunes, R.F.N.; Gomes, J.B.; Giardini, I.; da Silva, P.V.B.; Campos, É.; da Poça, K.S.; Hassan, R.; Otero, U.B.; Sarpa, M. Analysis of Benzene Exposure in Gas Station Workers Using Trans, Trans-Muconic Acid. Int. J. Environ. Res. Public Health 2020, 17, 5295. [CrossRef]

8. Tongsantia, U.; Chaiklieng, S.; Suggaravetsiri, P.; Andajani, S.; Autrup, H. Factors Affecting Adverse Health Effects of Gasoline Station Workers. Int. J. Environ. Res. Public Health 2021, 18, 10014. [CrossRef]

9. Ma, G.; Huang, Y. Safety assessment of explosions during gas stations refilling process. J. Loss Prev. Process. Ind. 2019, 60, 133-144. [CrossRef]

10. Sigut, M.; Alayón, S.; Hernández, E. Applying pattern classification techniques to the early detection of fuel leaks in petrol stations. J. Clean. Prod. 2014, 80, 262-270. [CrossRef]

11. Alayón, S.; Sigut, M.; Arnay, R.; Toledo, P. Time windows: The key to improving the early detection of fuel leaks in petrol stations. Saf. Sci. 2020, 130, 104874. [CrossRef]

12. Sikorova, A.K.; Bernatik, A.; Lunghi, E.; Fabiano, B. Lessons learned from environmental risk assessment within the framework of Seveso Directive in Czech Republic and Italy. J. Loss Prev. Process. Ind. 2017, 49, 47-60. [CrossRef]

13. Lee, M. New' Environmental Liabilities: The Purpose and Scope of the Contaminated Land Regime and the Environmental Liability Directive. Environ. Law Rev. 2009, 11, 264-278. [CrossRef]

14. Pouikli, K.C. Overview of the implementation of the directive 2004/35/EC on environmental liability with regard to the prevention and remedying of environmental damage at European level. Desalination Water Treat. 2016, 57, 11520-11527. [CrossRef] 
15. Staccione, A.; Mysiak, J.; Ostoich, M.; Marcomini, A. Financial liability for environmental damage: Insurance market in Italy, focus on Veneto region experience. Environ. Sci. Pollut. Res. 2019, 26, 25749-25761. [CrossRef]

16. Nigar, M. Environmental liability and global commons: A critical study. Int. J. Law Manag. 2018, 60, 435-451. [CrossRef]

17. Descamps, H. Natural resource damage assessment (NRDA) under the European Directive on Environmental Liability: A comparative legal point of view. Oceanis 2008, 32, 439-461.

18. Filentas, F.; Paralikas, A. Legal tools of environmental liability in Greece: Application in the broader region of Asopos. Int. J. Environ. Sustain. Dev. 2014, 13, 224-238. [CrossRef]

19. Czech, E.K. Liability for Environmental Damage According to Directive 2004/35/EC. Pol. J. Environ. Stud. 2007, 16, 321-324.

20. Cassota, S. Environmental Damage and Liability Problems in a Multilevel Context: The Case of the Environmental Liability Directive; Kluwer Law International: Bedfordshire, UK, 2012.

21. Ortega, J.M.; Brouwer, R.; Aiking, H. Application of a value-based equivalency method to assess environmental damage compensation under the European Environmental Liability Directive. J. Environ. Manag. 2011, 92, 1461-1470. [CrossRef]

22. Goisis, F.; Stefani, L. The polluter-pays principle and site ownership: The European jurisprudential developments and the Italian experience. J. Eur. Environ. Plan. Law 2016, 13, 18-237. [CrossRef]

23. Brans, E.H.P. The Environmental Liability Directive: Legal Background and Requirements. Equivalency Methods for Environmental Liability; Springer: Dordrecht, The Netherlands, 2018.

24. Directive 2004/35/CE of the European Parliament and of the Council of 21 April 2004 on Environmental Liability with Regard to the Prevention and Remedying of Environmental Damage. Available online: https://eur-lex.europa.eu/legal-content/EN/TXT/ ?uri=celex\%3A32004L0035 (accessed on 22 November 2020).

25. Ajman, N.N.; Zainun, N.Y.; Sulaiman, N.; Khahro, S.H.; Ghazali, F.E.M.; Ahmad, M.H. Environmental Impact Assessment (EIA) Using Geographical Information System (GIS): An Integrated Land Suitability Analysis of Filling Stations. Sustainability 2021, 13, 9859. [CrossRef]

26. Bernatík, A. Hazard and Risk Analysis. Available online: https://www.fbi.vsb.cz/export/sites/fbi/U3V/cs/materialy/U3V_ AnalyzaRizik.pdf (accessed on 13 May 2020).

27. Polorecka, M.; Svetlik, J.; Mitrengova, J. Professional education and preparation for the performance of professional fire services in the field of environmental interventions. In Proceedings of the 14th International Technology, Education and Development Conference, Valencia, Spain, 2-4 March 2020.

28. Smith, K. Environmental Hazards: Assessing and Reducing Disasters, 6th ed.; Routledge: London, UK; New York, NY, USA, 2013.

29. Stam, G.J.; Bottelberghs, P.H.; Post, J.; Bos, G.; Proteus, H. A technical and management model for aquatic risk assessment of industrial spills. J. Hazard. Mater. 2000, 71, 439-448. [CrossRef]

30. Andersson, A.S. Environment-Accident Index. A Planning Tool to Protect the Environment in Case of a Chemical Accident. Available online: https://www.diva-portal.org/smash/get/diva2:141970/FULLTEXT01.pdf (accessed on 15 April 2021).

31. Methodical Instruction No. 2 of the Department of Environmental Risks for the Determination of Environmental Vulnerability ENVITech03 and the Procedure for the Analysis of the Impacts of Accidents Involving a Dangerous Substance on the Environment Using the H\&V Index Method. Available online: https:/ / www.mzp.cz/web/edice.nsf/F5964CAB7EF17D95C12572590045E61A/ \$file/vestnik_03-2007_web.pdf (accessed on 8 December 2020).

32. Bernatík, A.; Nevrlá, P. Impact of Accidents on the Environment. Available online: https://www.fbi.vsb.cz/export/sites/fbi/04 0/.content/galerie-souboru/studijni-materialy/skripta_VHZP-2005 (accessed on 24 May 2020).

33. Zelenáková, M.; Labant, S.; Zvijáková, L.; Weiss, E.; Cepelová, H.; Weiss, R.; Fialová, J.; Mindas, J. Methodology for environmental assessment of proposed activity using risk analysis. Environ. Impact Assess. Rev. 2020, 80, 106333. [CrossRef]

34. Guidelines for Environmental Risk Assessment and Management. Available online: http://www.iehconsulting.co.uk/IEH_ Consulting/IEHCPubs/HumExpRiskAssess/guidelinesforenvironmental.pdf (accessed on 14 April 2021).

35. Gormley, Á.; Pollard, S.; Rocks, S. Guidelines for Environmental Risk Assessment and Management: Green Leaves III, 1st ed.; Cranfield University: Cranfield, UK, 2011. Available online: https://assets.publishing.service.gov.uk/government/uploads/system/ uploads/attachment_data/file/69450/pb13670-green-leaves-iii-1111071.pdf (accessed on 11 January 2021).

36. U.S. Environmental Protection Agency. Guidelines for Ecological Risk Assessment; EPA/630/R095/002F; Risk Assessment Forum: Washington, DC, USA, 1998. Available online: https:/ / www.epa.gov/sites/default/files/2014-11/documents/eco_risk_ assessment1998.pdf (accessed on 11 January 2021).

37. U.S. Environmental Protection Agency. Conducting an Ecological Risk Assessment. Available online: https:/ /www.epa.gov / risk/conducting-ecological-risk-assessment\#tab-2 (accessed on 15 March 2021).

38. Tixier, J.; Dusserre, G.; Salvi, O.; Gaston, D. Review of 62 risk analysis methodologies of industrial plants. Loss Prev. Process. Ind. 2002, 15, 291-303. [CrossRef]

39. Bernatík, A. Prevention of Major Accidents I. Available online: /http://www.portalbozp.cz/wp-content/uploads/2015/01/ Bernatik_skripta-PZH-I.pdf (accessed on 25 November 2020).

40. Bernatík, A. Prevention of Major Accidents II. Available online: https://www.fbi.vsb.cz/export/sites/fbi/040/.content/galeriesouboru/studijni-materialy/skripta-PZH-II.pdf (accessed on 25 November 2020).

41. United Kingdom's Health and Safety Authority (UKHSA) 2018. Petrol Station Safety. Available online: http://www.hsa.ie/eng/ Your_Industry / Petrol_Stations (accessed on 11 March 2021).

42. Mäkká, K.; Kampová, K. (University of Žilina, Žilina, Slovakia). Personal communication, 2020. 
43. Andersson, A.S.; Tysklind, M.; Fangmark, I. A method to relate chemical accident properties and expert judgements in order to derive useful information for the development of Environment-Accident Index. J. Hazard. Mater. 2007, 147, 524-533. [CrossRef] [PubMed]

44. Good, D.; Tynan, C.; Cleary, K. Environmental Liability Risk Assessment; Verde Environmental Consultants Ltd.: Wicklow, Ireland, 2016.

45. Mirae, Y.; Robby, C.; Bo, G.K.; Belal, A.; Jaehyun, H.; Sanghoon, L.; Hyun, G. A software tool for integrated risk assessment of spent fuel transportation and storage. Nucl. Eng. Technol. 2017, 49, 721-733.

46. Tahmid, M.; Dey, S.; Syeda, S.R. Mapping human vulnerability and risk due to chemical accidents. J. Loss Prev. Process. Ind. 2020, 68, 104289. [CrossRef]

47. Tang, Y.; Jing, J.J.; Zhang, Z.D.; Yang, Y. A Quantitative Risk Analysis Method for the High Hazard Mechanical System in Petroleum and Petrochemical Industry. Energies 2018, 11, 14. [CrossRef] 